\title{
Hemşirelik Öğrencilerinin Doğrudan Bakım Uygulamalarına Ayırdıkları Süre ve Bakım Davranışları Algısının Belirlenmesi
}

\author{
Nurcan UYSAL ${ }^{*}$ Y. Eda TEKİN**, Seda DEĞİRMENCI ÖZ***, \\ Behice Belkıs ÇALIŞKAN ${ }^{* * * *}$, Güldem YILDIZ ${ }^{* * * * *}$, Serpil YEDEK ${ }^{* * * * * *}$, \\ Nuran KÖMÜRCÜ********
}

$\ddot{O} \mathbf{z}$

Amaç: Araştırma, hemşirelik öğrencilerinin klinik uygulamalar sırasında doğrudan bakım uygulamalarına ayırdıkları zamanı ve öğrencilerin bakım davranışları algısını belirlemek amacıyla planlanmıştır.

Yöntem: Araştırma tanımlayıcı tipte olup araştırmanın örneklemini bir vakıf üniversitesinin hemşirelik bölümünde öğrenim gören birinci sınıflar hariç toplam 80 öğrenci oluşturmuştur. Çalışmanın verileri "Klinik Uygulamada Hemşirelik Öğrencilerinin Aktivitelerini İzlem Formu” ve "Bakım Davranışları Ölçeği” ile toplanmıştır. Veriler gözlem yoluyla elde edilmiştir.

Bulgular: Öğrencilerin klinikte bir uygulama gününde doğrudan bakım uygulamalarına harcadıkları süre;

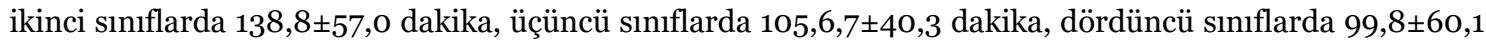
dakika olarak belirlenmiştir, Bakım uygulamaları dışındaki faaliyetlere ikinci sınıfların 50,2 $\pm 40,3$, üçüncü

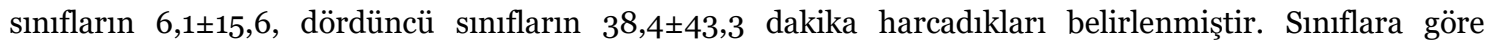
öğrencilerin doğrudan bakım ve diğer faaliyetlere harcadıkları süreler arasında istatistiksel olarak fark bulunmuştur ( $<<0,05)$. Öğrencilerinin Bakım Davranışları Ölçeği-24’ten aldıkları toplam puan ortalaması

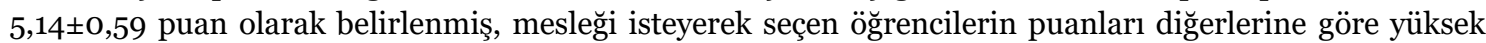
bulunmuştur. ( $<<0,05)$. Öğrencilerin bakım davranışları algıları olumlu olmasına rağmen, doğrudan bakım uygulamalarına ayırdıkları sürenin az olduğu belirlenmiştir.

Sonuç: Öğrencilerin bakım kalitesi algılarının yüksek olmasına rağmen, doğrudan bakım uygulamalarına ayırdıkları sürenin az olduğu belirlenmiştir.

Anahtar Sözcükler: Bakım, hemşirelik eğitimi, hemşirelik öğrencileri.

\footnotetext{
Özgün Araştırma Makalesi (Original Research Article)

Geliş / Received: 10.03.2021 \& Kabul / Accepted: 08.12.2021

DOI: https://doi.org/10.38079/igusabder.894802

${ }^{*}$ Doç. Dr., İstinye Üniversitesi, Sağlık Bilimleri Fakültesi, Hemşirelik Bölümü, İstanbul, Türkiye,

E-posta: nurcan.uysal@istinye.edu.tr ORCID https://orcid.org/oooo-0002-1325-9826

** Dr. Öğr. Üyesi, Beykent Üniversitesi, İstanbul, Türkiye, E-posta: edatekin@beykent.edu.tr

ORCID https://orcid.org/0000-0003-1567-0042

**** Dr. Öğr. Üyesi, İstanbul Aydın Üniversitesi, Sağllk Bilimleri Fakültesi, Hemşirelik Bölümü, İstanbul, Türkiye, E-posta: sedadegirmenci@aydin.edu.tr ORCID https://orcid.org/oooo-0002-4790-9639

**** Öğr. Gör., Beykent Üniversitesi, İstanbul, Türkiye, E-posta: bhcblksayan@gmail.com

ORCID https://orcid.org/o0o0-0001-7249-2954

***** Uzm. Hemşire, Medipol Mega Üniversite Hastanesi, Eğitim ve Gelişim Hemşiresi, İstanbul, Türkiye, E-posta: guldem.yildiz@medipol.com.tr ORCID https://orcid.org/o0oO-0002-9892-4126

***** Öğr. Gör., İstanbul Aydın Üniversitesi, Sağlık Bilimleri Fakültesi, Hemşirelik Bölümü, İstanbul, Türkiye, E-posta: serpilyedek@aydin.edu.tr ORCID https://orcid.org/o000-0002-2540-1762

${ }_{* * * * * * *}$ Prof. Dr., İstanbul Aydın Üniversitesi, Sağlık Bilimleri Fakültesi, Hemşirelik Bölümü, İstanbul, Türkiye, E-posta: nuran.komurcu@aydin.edu.tr ORCID https://orcid.org/o000-0003-1983-8287
}

ETIK BILLDIRİM: Araştırmanın uygulanabilmesi için İstanbul Aydın Üniversitesi Girişimsel Olmayan Araştırmalar Etik Kurulu'ndan izin alnmıştır (Tarih: 9.05.2019 Karar No: 2019/100). 


\title{
Identifying the Care Behavior Perception of Nursing Students and the Time They Allocated to the Direct Care Practices
}

\begin{abstract}
Aim: The research was planned for the purpose of identifying the time allocated by nursing students to direct care practices during clinical practices and the students' care behavior perceptions.

Method: The research was conducted as a descriptive type and the sample of the research consisted of 80 students in total, excluding first-year students studying in the nursing department of a foundation university. The data of study were collected with "Inspection Form for Nursing Students' Activities in Clinical Practices" and "Care Behaviors Scale". Data were collected by observation.

Results: The time allocated by the students to direct care practices during a practice day in clinic was identified as; $138,8 \pm 57,0$ minutes on average in second graders, $105,6,7 \pm 40,3$ minutes on average in third graders, and 99,8 $\pm 60,1$ minutes on average in fourth graders, It was identified that the second graders spend $50,2 \pm 40,3$ minutes, the third graders spend $6,1 \pm 15,6$ minutes, and the fourth graders spend $38,4 \pm 43,3$ minutes for the practices other than care practices. It was statistically found a difference between the times allocated by the students to direct care and other practices with regard to grades $(\mathrm{p}<0,05)$. The total average score of the students in Care Behaviors Scale-24 was identified as 5,14 $\pm 0,59$, and the scores of the students who chose the profession voluntarily were found as higher than the other students. $(p<0,05)$. Although the students' perceptions of care behaviors were positive, it was determined that the time they allocated to direct care practices was less.
\end{abstract}

Conclusion: It was identified that although the care quality perception of the students are high, the time they allocated to direct care practices is low.

Keywords: Care, nursing education, nursing students.

\section{Giriş}

Bakım ölçülmesi ve tanımlanması zor bir kavram olmakla birlikte hemşireliğin özüdür¹. Bakım, yapılan işlemlere ilişkin hastanın bilgilendirilmesi, bireyselliğine önem verilmesi, kendi kendine karşılayamadığı gereksinimlerinin karşılanması, bireylere destek sağlanması, hastalıklarla baş etmesine yardım edilmesi ve kişilerarası iletişim becerilerinin geliştirilmesidir ${ }^{2,3}$. Bakım kavramı, hemşireler için etik kodlar gibi temel mesleki konu alanlarının odak noktası olmakla birlikte 4 hemşirelik eğitiminin de temel noktasını oluşturmaktadır. Bu nedenle öğrencilerin bakım davranışlarının pekiştirilmesinde klinik uygulamanın yeri oldukça önemlidir.

Türkiye'de yükseköğretim kurumları için belirlenen eğitim standartlarına göre; 4600 saatlik hemşirelik eğitim süresinin yarısını klinik eğitimler oluşturmaktadır. Klinik eğitimler, öğrencinin hemşirelik mesleğini yapabilmesi için yeterli klinik deneyime sahip olması amacıyla uygulanmaktadır5. Günümüzde öğrenci sayısının fazlalığı ve uygulama alanlarının yetersizliğine bağlı olarak yaşanan güçlükler uygulamalarda geçen sürenin etkin ve verimli kullanılmasına engel teşkil etmektedir. Yapılan çalışmalar, uygulamalarda kurumların fiziki koşulları, sağlık personeli, eğiticiler ve öğrencinin kendisinden kaynaklanan çeşitli sorunlar yaşandığını ve öğrencilerin uygulamalardan istenilen düzeyde yararlanamadığını ortaya koymuştur ${ }^{6-8}$. Literatürde yer alan çalışmalarda, öğrencilerin bakım işlevlerinden çok kliniklerde görev dışı farklı işler yaptırıldığı belirlenmiştir9,10. Yaşanan tüm sorunlara rağmen hemşire eğiticiler klinik uygulamalarda, uygulama hedefleri ve hastanın bakım gereksinimi doğrultusunda öğrencileri doğrudan bakım uygulamalarını yerine getirmeleri için yönlendirmekte ve hastaya bütüncül yaklaşım sağlayacak davranışlar geliştirmeleri için rehberlik etmektedir. 
Bakım davranışları bütüncül hemşirelik yaklaşımı, eleştirel düşünme ve hemşirelik süreci ile

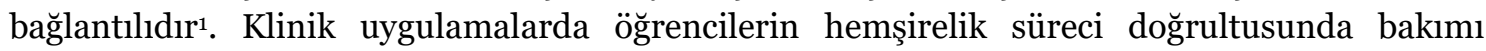
planlayarak hastaya bütüncül bakım vermesi ve sürecin tüm yönlerini eleştirel gözle değerlendirebilmesi beklenir. Bu nedenle öğrencilerin belirlenen hedefler doğrultusunda verimli ve etkin bir eğitim alabilmesi için klinikte geçen sürenin çok iyi değerlendirilmesini oldukça önemlidir. Polifroni ve ark. (1995) dokuz klinikte öğrencilerin zamanlarını nasıl kullandı̆̆ını belirledikleri gözlemsel çalışma bazı yönleri ile benzerlik gösterse de faaliyetlerin sınıflandırılmasında farklılıklar bulunmaktadır. Çalışmada öğrencilerin klinikteki geçirdikleri süreler eğitimci, sorumlu hemşire ve primer hemşire ile geçirilen süreler olarak tanımlanmıştır. Öğrencilerin zamanlarının yalnızca \%25’ini eğitici, sorumlu hemşire ve primer hemşire ile birlikte geçirdiği, geri kalan \%75'lik zamanda denetimsiz kaldığı belirlenmiştir ${ }^{11}$. Literatürde öğrencilerin bakım davranışları algısına yönelik yapılan çalışmalara rastlanırken3,4,12-19 öğrencilerin klinik uygulamalarda hangi işlevlere ne kadar süre harcadıkları, özellikle doğrudan bakım uygulamalarında geçirdikleri sürelerin belirlendiği çalışmalara rastlanmamıştır. Bu araştırma; hemşirelik öğrencilerinin klinik uygulamalar sırasında doğrudan ve doğrudan olmayan bakım uygulamalarına ayırdıkları zaman ile bakım davranışları algılarının değerlendirilmesi amacıyla planlanmıştır.

\section{Gereç ve Yöntem}

Araştırma tanımlayıcı tipte olup, araştırmanın evrenini bir vakıf üniversitesinin hemşirelik bölümü iki $(n=40)$, üç $(n=35)$ ve dördüncü sınıfta öğrenim gören $(n=45)$ toplam 120 öğrenci oluşturmuştur. Çalışmaya gönüllü olan 80 öğrenci dahil edilmiştir (\%66.6). Birinci sınıf öğrencileri klinik uygulamaya çıkmadıkları için araştırmaya dahil edilmemiştir. İkinci sınıf öğrencileri Cerrahi ve İç Hastalıkları Hemşireliği dersi, üçüncü sınıf öğrencileri Geriatri Hemşireliği dersi ve dördüncü sınıf öğrencileri intörnlük uygulaması için klinik uygulamaya çıkmıştır. Kliniklerde iki rehber hemşire ve yedi öğretim elemanı görevlidir.

Verilerin toplanmasında araştırmacılar tarafından hazırlanan "Demografik Bilgi Formu”, "Klinik Uygulamada Hemşirelik Öğrencilerinin Aktivitelerini İzlem Formu" ve "Bakım Davranışları Ölçeği-24 (BDÖ-24)” kullanılmıştır. BDÖ-24, Wolf ve arkadaşları ${ }^{20}$ (1994) tarafından geliştirilmiş, ölçeğin Türkçe geçerlik ve güvenirlik çalışmaları Kurşun ve Kanan (2012) tarafından yapılmıştır². Ölçek; güvence (8 madde), bilgi-beceri (5 madde), saygılı olma (6 madde), bağlllık ( 5 madde) olmak üzere 4 alt grup ve toplam 24 maddeden oluşmaktadır. Puan hesaplanmasında; tüm madde puanları toplanıp 24'e bölünmesi sonucunda 1-6 arasında toplam ölçek puanı, alt boyutlarda yer alan madde puanları toplanarak madde sayısına bölünmesi ile 1-6 arasında alt boyut ölçek puanları elde edilmektedir. Puan arttıkça bakım davranışları algı düzeyi artmaktadır. Ölçeğin Cronbach alfa katsayısı 0.97 olarak belirlenmiş, bu araştırmada ise değer 0.95 olarak hesaplanmıştır. Klinik uygulamanın sonunda BDÖ-24 ölçeği öğrenciler tarafından sınıfta doldurulmuştur.

Klinik Uygulamada Hemşirelik Öğrencilerinin Aktivitelerini İzlem Formu; uygulama sırasında öğrencilerin hangi aktiviteye ne kadar zaman harcadığını kaydetmek amacıyla öğretim elemanı tarafından doldurulmuştur. Form, doğrudan bakım uygulamaları, bakım uygulamaları dışındaki faaliyetler ve bireysel faaliyetler olmak üzere 3 kategoriden oluşmaktadır. Veriler, Şubat-Haziran 2019 tarihleri arasında klinik uygulama sırasında gözlem yoluyla toplanmıştır. Öğrencilerin aktivitelere ayırdıkları süre; klinik uygulamalar süresince her öğrencinin iki uygulama günü boyunca öğretim elemanı tarafından gözlemlenmesi ile elde edilmiştir. Verilerin analizinde sayı ve yüzdelik hesabı, ANOVA ve t testi kullanılmıştır. Araştırmanın uygulanabilmesi için İstanbul Aydın Üniversitesi Girişimsel Olmayan Araştırmalar Etik Kurulu’ndan (Tarh: 9.05.2019 Karar 
No: 2019/100) ve öğrencilerden bilgilendirilmiş yazılı onam alınmıştır.

\section{Bulgular}

Çalışmaya dâhil edilen öğrencilerin \%40,o'ını ikinci sınıf, \%36,2'sini üçüncü sınıf olup öğrencilerin \%71,2'si kız, \%10,o’ı sağllk meslek lisesi mezunu ve \%42,5’i mesleği isteyerek seçmiştir (Tablo 1).

Tablo 1. Öğrencilerin demografik özellikleri

\begin{tabular}{|l|l|l|}
\hline Demografik özellikler & Sayı & Yüzde \\
\hline Yaş & \multicolumn{2}{|l|}{ X= 21,72 (min: 19 max: 30) } \\
\hline Sinıf & \multicolumn{2}{|l|}{} \\
2. Sinıf & 19 & 23,8 \\
3. Sinıf & 32 & 40,0 \\
4. Sinıf & 29 & 36,2 \\
\hline Cinsiyet & & \\
Kız & 57 & 71,2 \\
Erkek & 23 & 28,8 \\
\hline Mezun olduğu okul & & \\
Sağlık Meslek Lisesi & 8 & 10,0 \\
Diğer & 70 & 90,0 \\
\hline Mesleği isteyerek seçme & & \\
Evet & 34 & 42,5 \\
Hayır & 46 & 57,5 \\
\hline
\end{tabular}

Çalışmada, doğrudan bakım uygulamalarına en fazla $138,8 \pm 57,0$ dakika ile ikinci sınıf öğrencilerinin zaman harcadığı belirlenmiştir. Veri toplama ve bakım planı yazmaya $51,2 \pm 19,3$ dakika ile en fazla dördüncü sınıf öğrencileri zaman harcamışlardır. Bakım uygulamaları dışındaki faaliyetlere 502 $\pm 40,3$ dakika ile ikinci sınıflar, bireysel faaliyetlere 127,2 $\pm 18,6$ dakika ile en fazla üçüncü sınıflar zaman harcamışlardır (Tablo 2). Sınıflara göre doğrudan bakım ve bakımla ilgili olmayan klinik faaliyetlere harcanan süreler arasında istatistiksel olarak anlaml fark bulunmuştur. Yapılan ileri analizde farkın ikinci sınıflardan kaynaklandığı, ikinci sınıf öğrencilerinin doğrudan bakım uygulamalarına ve bakımla ilgili olmayan klinik faaliyetlere diğer sınıflara göre daha çok zaman harcadıkları belirlenmiştir ( $p>0,05)$. Bireysel faaliyetlere harcanan zamana göre sinıflar arasında istatistiksel olarak farklılık bulunmuş, farkın üçüncü sınıf öğrencilerden kaynaklandığı ve daha fazla zaman harcadıkları belirlenmiştir $(\mathrm{p}<0,05)$. Sinıflara göre veri toplama ve bakım planı yazmak için geçirilen süreler arasında istatistiksel olarak bir farklılık bulunmamıştır ( $>0$,05) (Tablo 2).

Tablo 2. Sınıflara göre harcanan zamanların karşılaştırılması

\begin{tabular}{|l|l|l|l|l|l|}
\hline Faaliyetler & \multicolumn{2}{|l|}{ 2. Sınıf } & \multicolumn{2}{|l|}{ 3. Sinıf } & \multicolumn{2}{l|}{ 4. Sınıf } & F & p \\
& X SS & X SS & X SS & & \\
\hline Doğrudan bakım uygulamaları & $138,8 \pm 57,0$ & $105,6 \pm 40,3$ & $99,8 \pm 60,1$ & $3,52^{*}$ & .034 \\
\hline Veri toplama ve bakım planı yazma & $42,8 \pm 10,9$ & $46,0 \pm 22,2$ & $51,2 \pm 19,3$ & $1,181^{*}$ & .312 \\
\hline Bakımla ilgili olmayan klinik faaliyetler & $50,2 \pm 40,3$ & $6,1 \pm 15,6$ & $38,4 \pm 43,3$ & $11,980^{*}$ & .000 \\
\hline Bireysel faaliyetler & $97,7 \pm 20,0$ & $127,2 \pm 18,6$ & $109,3 \pm 9,8$ & $20,864^{*}$ & .000 \\
\hline
\end{tabular}

*ANOVA testi uygulanmıştır.

Öğrencilerin doğrudan bakım uygulamaları incelendiğinde, ikinci sınıf öğrencilerinin en fazla yaşam bulguları ölçümü $(35,2 \pm 28,0 \mathrm{dk})$ ve tedaviye yardım etmeye $(30,2 \pm 16,9 \mathrm{dk})$ zaman 
harcadıkları belirlenmiştir. Üçüncü sınıfların yara bakımına $(29,4 \pm 26,6 \mathrm{dk})$ ve veri toplamaya $(28,9 \pm 2,5 \mathrm{dk})$, dördüncü sınıfların bakım planı yazmaya $(37,4 \pm 16, \mathrm{o} \mathrm{dk})$ ve yaşam bulguları ölçümüne (22,4 $\pm 24,0 \mathrm{dk})$ daha fazla zaman harcadıkları saptanmıştır (Tablo 3).

Bakım uygulamaları dışındaki faaliyetlere en fazla, dördüncü sınıf öğrencilerinin malzeme

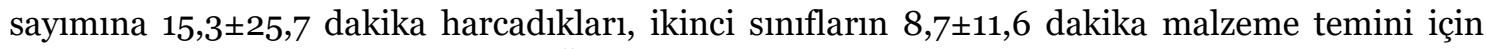
zaman harcadıkları belirlenmiştir. Üçüncü sınıf öğrencilerinin bakım dışındaki faaliyetler için diğer sınıflara göre daha az zaman harcadıkları, en fazla ilaç yerleştirmeye 2,6 $\pm 15,0$ dakika zaman harcadıkları belirlenmiştir. Bireysel faaliyetlerde öğle yemeğine en fazla zaman ayrıldığı belirlenmiştir. Öğrencilerin boş oturarak geçirdikleri zaman üçüncü sinfflarda $(18,3 \pm 12,5 \mathrm{dk})$ diğer sınıflara göre daha yüksek bulunmuştur. (Tablo 3).

Tablo 3. Sinıflara göre klinik uygulamalarda geçirilen sürenin faaliyetlere göre dağılımı

\begin{tabular}{|c|c|c|c|}
\hline Doğrudan bakım uygulamalarına ilişkin faaliyetler & $\begin{array}{l}\text { 2. Sinif } \\
X_{ \pm} \pm S S\end{array}$ & $\begin{array}{c}\text { 3. Sinif } \\
X \pm S S\end{array}$ & $\begin{array}{l}\text { 4. Sinif } \\
X_{ \pm} \text {SSS }\end{array}$ \\
\hline Veri toplama & $26,0 \pm 9,8$ & $28,9 \pm 22,5$ & $13,7 \pm 7,6$ \\
\hline Bakım planı yazma & $16,8 \pm 6,0$ & $17,1 \pm 5,9$ & $37,4 \pm 16,0$ \\
\hline Yaşam bulguları ölçümü & $35,2 \pm 28,0$ & $14,9 \pm 18,5$ & $22,4 \pm 24,0$ \\
\hline Ağız bakımı & $1,5 \pm 4,7$ & $9,6 \pm 16,8$ & $2,1 \pm 0,8$ \\
\hline Yatak banyosu & $2,4 \pm 5,3$ & $0 \pm 0,0$ & $1,7 \pm 0,7$ \\
\hline Saç bakımı & $1,3 \pm 3,5$ & $0,5 \pm 1,7$ & - \\
\hline Yara bakımı & $13,4 \pm 13,6$ & $29,4 \pm 26,6$ & $11,5 \pm 11,0$ \\
\hline Postop hasta karşlama & $7,9 \pm 14,7$ & $1,0 \pm 3,8$ & $2,3 \pm 12,4$ \\
\hline Hastayı besleme & $1,5 \pm 4,7$ & $24,2 \pm 21,7$ & $2,7 \pm 5,6$ \\
\hline Mobilizasyon & $14,0 \pm 20,4$ & $3,2 \pm 6,4$ & $1,3 \pm 4,2$ \\
\hline Pozisyon vermek & $8,3 \pm 10,1$ & $4,1 \pm 6,3$ & $8,1 \pm 13,4$ \\
\hline Damar yolu açmak & $14,3 \pm 17,9$ & $1,4 \pm 1,9$ & $2,1 \pm 6,0$ \\
\hline Oksijen tedavisi & $0,5 \pm 2,2$ & - & $0,5 \pm 0,9$ \\
\hline Foley kateter takma & $0,1 \pm 9,1$ & - & $1,0 \pm 1,8$ \\
\hline EKG çekme & $10,7 \pm 15,4$ & $1,0 \pm 3,9$ & $2,9 \pm 5,7$ \\
\hline Kan şekeri ölçümü & $1,8 \pm 8,0$ & $0,5 \pm 2,7$ & $3,3 \pm 6,1$ \\
\hline Kan alma & $7,8 \pm 6,9$ & $1,0 \pm 1,0$ & $2,5 \pm 7,6$ \\
\hline Tedaviye yardım etme & $30,2 \pm 16,9$ & $15,4 \pm 13,5$ & $6,1 \pm 8,8$ \\
\hline Eğitim verme & $16,4 \pm 11,6$ & $2,9 \pm 4,9$ & $5,5 \pm 15,6$ \\
\hline \multicolumn{4}{|l|}{ Bakım uygulamaları dışındaki faaliyetler } \\
\hline Tetkik için örnek götürme & $5,5 \pm 8,8$ & - & $5,7 \pm 15,6$ \\
\hline Hasta transportu & $5,1 \pm 7,4$ & - & $4,1 \pm 8,9$ \\
\hline Bilgisayara veri girişi & $2,8 \pm 5,3$ & $1, \mathrm{O} \pm 1,7$ & $3,0 \pm 5,0$ \\
\hline Hasta kimlik kontrolü yapma & $4,2 \pm 5,6$ & $1,0 \pm 1,7$ & $1,0 \pm 1,2$ \\
\hline Yatış işlemlerine yardım & $5, \mathrm{O} \pm 8,3$ & - & $2,2 \pm 4,7$ \\
\hline İlaç yerleştirme & $8,9 \pm 9,5$ & $2,6 \pm 15,0$ & $1,1 \pm 3,2$ \\
\hline Malzeme temini & $8,7 \pm 11,6$ & - & $6,5 \pm 16,7$ \\
\hline Malzeme sayımı & $5,7 \pm 8,3$ & - & $15,3 \pm 25,7$ \\
\hline \multicolumn{4}{|l|}{ Bireysel faaliyetler } \\
\hline Giyinme & $16,0 \pm 4,8$ & $15,6 \pm 6,8$ & $14,6 \pm 1,3$ \\
\hline Çay içme & $15,2 \pm 3,8$ & $15,0 \pm 0,0$ & $15,0 \pm 1,0$ \\
\hline Öğle yemeği & $45,0 \pm 14,5$ & $58,4 \pm 6,2$ & $55,8 \pm 9,4$ \\
\hline Telefon görüşmesi & $9,6 \pm 2,3$ & $22,9 \pm 16,3$ & $10,8 \pm 2,7$ \\
\hline Boş oturma & $15,5 \pm 16,2$ & $18,3 \pm 12,5$ & $14,3 \pm 12,1$ \\
\hline
\end{tabular}


Çalışmaya dâhil edilen hemşirelik öğrencilerinin BDÖ-24'ten aldıkları toplam puan ortalaması $5.14 \pm 0.59$ olarak belirlenmiş, ölçeğin alt boyutlarından sırasıyla en yüksek bilgi ve beceri $5,19 \pm 0,56$ puan, güvence $5,07 \pm 0,92$ puan, saygılı olma 5,01 $\pm 0,61$ puan, bağlılık 4,16 $\pm 0,59$ puan olarak hesaplanmıştır (Tablo 4).

Tablo 4. Öğrencilerin BDÖ-24 puan ortalamalarının dağılımı

\begin{tabular}{|l|l|l|l|l|}
\hline Ölçek ve ölçek alt boyutları & Min & Max & X & SS \\
\hline Bilgi beceri & 3,80 & 6,0 & 5,19 & 0,56 \\
\hline Güvence & 3,38 & 6,0 & 5,07 & 0,92 \\
\hline Saygılı Olma & 3,80 & 6,0 & 5,01 & 0,61 \\
\hline Bağlılık & 3,17 & 5,0 & 4,16 & 0,51 \\
\hline BDÖ-24 & 4,17 & 6,0 & 5,14 & 0,59 \\
\hline
\end{tabular}

Öğrencilerin demografik özellikleri ile BDÖ-24 puan ortalamaları karşılaştırıldığında, cinsiyet, mezun olunan okul türü ve sinıflara göre istatistiksel olarak anlamlı bir farklılık bulunmamıştır (p>0,05). Mesleği isteyerek seçen öğrencilerin ölçek puan ortalaması 5,42 $\pm 0,41$, istemeyerek seçen öğrencilerin 4,94 $\pm 0,62$ puan olarak belirlenmiş ve aralarında istatistiksel olarak anlamlı fark bulunmuştur (Tablo 5).

Tablo 5. Öğrencilerinin demografik özellikleri ile BDÖ-24 puan ortalamalarının karşılaştırılması

\begin{tabular}{|c|c|c|c|c|c|}
\hline \multirow[t]{2}{*}{ Demografik özellikler } & \multirow[b]{2}{*}{$\mathrm{N}$} & \multicolumn{2}{|c|}{ Ölçek puan ortalaması } & \multirow[b]{2}{*}{$\mathrm{t}$} & \multirow[b]{2}{*}{$\mathrm{p}$} \\
\hline & & $\mathrm{X}$ & SS & & \\
\hline $\begin{array}{l}\text { Cinsiyet } \\
\text { Kız } \\
\text { Erkek }\end{array}$ & $\begin{array}{l}57 \\
23\end{array}$ & $\begin{array}{l}5,22 \\
4,96\end{array}$ & $\begin{array}{l}0,60 \\
0,52\end{array}$ & $1,745^{*}$ & 0,085 \\
\hline $\begin{array}{l}\text { Mezun olunan okul } \\
\text { SML } \\
\text { Diğer }\end{array}$ & $\begin{array}{l}8 \\
72\end{array}$ & $\begin{array}{l}4,92 \\
5,17\end{array}$ & $\begin{array}{l}0,66 \\
0,58\end{array}$ & $-1,145^{*}$ & 0,256 \\
\hline $\begin{array}{l}\text { Mesleği isteyerek seçme } \\
\text { Evet } \\
\text { Hayır }\end{array}$ & $\begin{array}{l}34 \\
46\end{array}$ & $\begin{array}{l}5,42 \\
4,94\end{array}$ & $\begin{array}{l}0,41 \\
0,62\end{array}$ & $4,150^{*}$ & 0,000 \\
\hline $\begin{array}{l}\text { Sinif } \\
\text { 2. Sinif } \\
\text { 3. Sinif } \\
\text { 4. Sinif } \\
\end{array}$ & $\begin{array}{l}19 \\
32 \\
29 \\
\end{array}$ & $\begin{array}{l}4,89 \\
5,25 \\
5,19\end{array}$ & $\begin{array}{l}0,70 \\
0,52 \\
0,55 \\
\end{array}$ & $2,363^{* *}$ & 0,101 \\
\hline
\end{tabular}

* t testi uygulanmıştır.

**ANOVA testi uygulanmıştır.

\section{Tartışma}

Tartışma iki bölümden oluşmakta olup ilk bölümde öğrencilerin klinik uygulamada doğrudan ve doğrudan olmayan bakım faaliyetleri ile bireysel faaliyetlere harcadıkları zaman tartışılmıştır. İkinci bölümde öğrencilerin BDÖ-24’ten aldıkları puanlar ve bu puanlara sosyo-demografik özelliklerin etkisi tartışılmıştır. Literatürde ilk bölümle ilgili yeterli araştırma olmaması nedeniyle sonuçlar yorumlanarak açılanmıştır.

\section{1. Öğrencilerin Klinik Uygulama Faaliyetleri}

Yaptığımız çalışmada öğrencilerin doğrudan bakım uygulamalarına yeterince zaman ayırmadığı, klinikte geçen sürenin yalnızca üçte birinin doğrudan bakım uygulamaları ile geçtiği 
belirlenmiştir. Polifroni ve ark. (1995) çalışmasında, hemşirelik öğrencilerinin klinikte geçirdikleri zamanın yalnızca \%44'ünü doğrudan hasta bakım faaliyetlerine harcadıkları ve bu sürenin yetersiz olduğu belirlenmiştir ${ }^{11}$. Doğrudan bakım uygulamalarına ayrılan süre ikinci sınıflarda diğer iki sınıfa göre yüksek olarak belirlenmiştir. Bu durum, ikinci sınıf öğrencilerinin Hemşirelik Esasları dersinde öğrendikleri becerileri hasta üzerinde uygulama isteği ve ilk kez kliniğe çıkmanın verdiği heyecanından kaynaklandığı söylenebilir. Doğrudan bakım uygulamalarında çoğunlukla; ikinci sınıf öğrencilerinin yaşam bulguları ölçümü, tedaviye yardım etme ve veri toplama, üçüncü sınıfların yara bakımı, veri toplama ve hastanın beslenmesine yardım etme, dördüncü sınıfların veri toplamaya ve bakım planı yazma ile yaşam bulguları ölçümü uyguladıkları saptanmıştır. Khademian ve Vizeshfar'ın (2008) çalışmasında, öğrencilerin en fazla hastanın ilaç tedavilerini zamanında uygulama, hastaya hastalığı, tedavisi ve öz bakımı hakkında bilgi vermeyi en önemli bakım davranışları olarak gördükleri belirlenmiştir ${ }^{21}$. Doğrudan bakım uygulamalarına ayrılan sürenin yetersizliği literatürde belirtilen klinik uygulamalarda yaşanan güçlüklerden kaynaklandığı söylenebilir.

Bakım uygulamaları dışındaki faaliyetlere ikinci sınıf öğrencilerinin daha fazla, üçüncü sınıfların ise en az zaman harcadıkları belirlenmiştir. En çok zaman harcanan faaliyetlerin malzeme temini, ilaçların yerleştirilmesi ve malzemelerin sayılması olduğu belirlenmiştir. Yapılan bir çalışmada, öğrencilerin uygulamalarda evrak taşıma, laboratuvara hasta götürme gibi görevleri yerine getirdikleri belirlenmiştir ${ }^{9}$. Karadağ ve ark. (2013) çalışmasında uygulamada yaşanan sorunların temel nedeninin öğrencilerin görevleri dışında işleri yerine getirmekten kaynaklandığını bildirmiştir ${ }^{10}$. Hemşirelerin, bakım işlevleri dışında kliniğin diğer rutin işleri için öğrencilerden yardım almaları doğal olarak öğrencilerin bu tür faaliyetlere gereğinden fazla zaman ayırmaları ile sonuçlanmaktadır. Bu sorunun aynı zamanda uygulama alanlarında öğretim elemanı yetersizliğinde de kaynaklandığı düşünülmektedir. Bireysel faaliyetlere harcanan zaman incelendiğinde, tüm sınıfların en fazla öğle yemeğine zaman ayırdığı belirlenmiştir. Bu sürenin, kurumların öğrencilere öğle yemeği imkanı sunmamasından kaynaklı olduğu söylenebilir. Ayrıca üçüncü sınıfların, boş oturarak geçirdikleri zaman ve bireysel telefon görüşmelerine ayırdıkları zaman diğer sinıflara göre daha yüksek bulunmuştur. Üçüncü sinıf öğrencilerinin uygulama alanlarının huzurevi olması ve kurum politikasına göre öğrenci faaliyetlerinin sinırlandırılmasından kaynaklı olduğu varsayılmaktadır.

\section{Bakım Davranışları Ölçeği-24}

Bulgulara göre, öğrencilerin bakım davranışları algısının yüksek olduğu söylenebilir. Bu sonuç hemşirelik öğrencileri ile yapılan diğer araştırma bulgularıyla benzerlik göstermektedir4,14-21. Öğrencilerin, bakım davranışları algısının yüksek olması olumlu bir durum olup, hemşireliğin özü olan bakımın hemşirelik eğitiminde önemle üzerinde durulması sonucunda öğrencilerde bu farkındalığın oluştuğu söylenebilir.

Çalışmamızda öğrencilerin BDÖ-24 ölçeğinin alt boyutlarından da yüksek puan aldıkları belirlenmiştir. En yüksek puanın bilgi ve beceri alt boyutundan, en düşük puanın bağlllık alt boyutundan alındığı belirlenmiştir. Bu sonuç, bilimsel yazındaki diğer çalışmalarla benzerlik gösterip 15,17,20-23 farklı olarak Türk ve ark. (2018) yaptığı çalışmada, en yüksek puan saygılı olma alt boyutunun, en düşük puan da bilgi-beceri ve bağlılık alt boyutunun olduğu saptanmıştır19. Öğrencilerin, demografik özellikleri ile bakım davranışları ölçeği puan ortalamalarının karşılaştırılmasında, mesleği isteyerek seçen öğrencilerin bakım davranışları algısı yüksek bulunmuştur. Türk ve ark. (2018) yaptıkları çalışmada öğrencilerin hemşirelikte meslek seçimi ve bakım davranışları algısı ölçekleri arasında pozitif yönde bir ilişki olduğu saptanmıştır'19. Yapılan diğer çalışmalarda da hemşirelik mesleğini isteyerek seçen öğrencilerin bakım davranışları algı 
puanlarının yüksek olduğu belirlenmiştir4,24-26. Hemşirelik mesleğini isteyerek seçen öğrencilerin klinik uygulamalarda daha hevesli ve mesleğinden daha fazla doyum alarak çalıştıkları ve bakım davranışları algısına olumlu yansıdığı söylenebilir.

Öğrencilerin cinsiyeti, mezun olduğu okul ve sınıflara göre BDÖ-24 ölçek puan ortalamaları arasında istatistiksel olarak anlamlı bir fark olmadığı saptanmıştır. Benzer olarak literatürde hemşirelerle yapılan çalışmalarda da cinsiyet ve mezun olunan okulun bakım davranışları algısı üzerine etkili olmadığı belirlenmiştir ${ }^{17,20,23}$. Türk ve ark'nın (2018) çalışmasında kız öğrencilerin BDÖ-24 toplam puan ortalaması ve güvence, saygı ve bağlılık alt boyutlarından aldıkları puan ortalamalarının erkek öğrencilerde daha yüksek olduğu belirlenmiştir ${ }^{19}$. Gül ve Arslan'ın çalışmasında da öğrencilerin cinsiyet ve öğrenim gördükleri sınıflarına göre bakım davranışları ölçeğinden aldıkları puanlar arasında anlamlı farklılık olduğu belirlenmiştir. Yaptığımız çalışmada cinsiyet, mezun olunan okul ve sınıflara göre bakım davranışları algı puanlarının farklı olmaması olumlu olarak değerlendirilmiş olup bakımın öğrenciler tarafından önemsendiği ve mesleğin odak noktası olarak gördükleri şeklinde açıklanabilir.

\section{Sonuç ve Öneriler}

Öğrencilerin bakım davranışları algıları olumlu olmasına rağmen, doğrudan bakım uygulamalarına ayırdıkları sürenin az olduğu belirlenmiştir. Hasta bakımına ayrılan sürenin arttırılması için öğrencilerin rolleri dışında görevler yüklenmemesi gerekmektedir. Bunun için klinik uygulama hedeflerinin yönetici hemşireler, eğitim hemşireleri, klinik sorumlu hemşireleri ile paylaşılması, uygulama alanlarında yaşanan sorunların çözümü için işbirliği yapılması önerilmektedir. Ayrıca uygulamalara öğrencilerle birlikte çıkan öğretim elemanı sayılarının arttırılması gereklidir.

\section{Sinırlılıklar}

Araştırmanın örneklemini yalnızca bir üniversitede öğrenim gören hemşirelik öğrencilerinin oluşturması ikinci kısıtlılık olarak belirlenmiştir ve bu nedenle elde edilen sonuçlar tüm evrene genellenemez.

\section{KAYNAKLAR}

1. Chen SY, Chang HC, Pai HC. Caring behaviours directly and indirectly affect nursing students' critical thinking. Scandinavian Journal of Caring Sciences. 2018;32(1):197-203. doi:10.1111 / scs.12447.

2. Kurşun Ş, Kanan N. Bakım davranışları ölçeği-24'ün Türkçe formunun geçerlik ve güvenirlik çalışması. Anadolu Hemşirelik ve Sağllk Bilimleri Dergisi. 2012;15:4.

3. Li YS, Yu WP, Yang BH, Liu CF. A comparison of the caring behaviours of nursing students and registered nurses: Implications for nursing education. Journal of Clinical Nursing. 2016;25(21-22):3317-3325. doi:10.1111 / jocn.13397.

4. Birimoğlu C, Ayaz S. Hemşirelik öğrencilerinin bakım davranışlarını algılamaları. Hacettepe Üniversitesi Hemşirelik Fakültesi Dergisi. 2015;2(3):40-48.

5. Yükseköğretim Kurulu. Doktorluk, hemşirelik, ebelik, diş hekimliği, veterinerlik, eczacılık ve mimarlık eğitim programlarının asgari eğitim koşullarının belirlenmesine dair yönetmelik. TC Cumhurbaşkanlığı Mevzuat Bilgi Sistemi. https://www.mevzuat.gov.tr/mevzuat?MevzuatNo=11949\&MevzuatTur=7\&MevzuatTertip =5.Yayınlanma tarihi 02 Şubat 2008. Erişim tarihi 5 Temmuz 2020. 
6. Akgün KM, Aras T, Akarsu Ö. Hemşirelik öğrencilerinin klinik hemşirelerinin eğitimlerine verdiği katkıya ilişkin görüşleri. Cumhuriyet Hemş. Dergisi. 2012;2:39-46.

7. Efil S, Küçükakgün H, Gül E, Kapıcı M. Öğrencilerin iç hastalıkları hemşireliği dersinin klinik uygulamasında yaşadıkları sorunlar. Sağlık ve Yaşam Bilimleri Dergisi. 2019;1(2):16. doi:10.33308/2687248X.201912142.

8. Karaöz S. Hemşirelik eğitiminde klinik değerlendirmeye genel bakış: Güçlükler ve öneriler. DEUHYO ED. 2013;6(3):149-158.

9. Aydın MF, Argun MŞ. Bitlis Eren Üniversitesi sağlık yüksekokulu hemşirelik bölümü öğrencilerinin hastane uygulamalarından beklentileri ve karşılaştıkları sorunlar. Acıbadem Üniversitesi Sağhk Bilimleri Dergisi. 2010;1(4):209-213.

10. Karadağ G, Kılıç SP, Ovayolu N, Ovayolu Ö, Kayaaslan H. Öğrenci hemşirelerin klinik uygulamada karşılaştıkları güçlükler ve klinik hemşireler hakkındaki görüşleri. TAF Preventive Medicine Bulletin. 2013;12(6):665-667. doi:10.5455/pmb.1-1353569323.

11. Polifroni CE, Packard AS, Shah SH, Macavoy S. Activities interactions of baccalaureate nursing students clinical practica. J. Professional Nursing. 1995;11(3):161-169. doi:10.1016/S8755-7223(95)80115-4.

12. Aktaş YY, Karabulut N. Professional values in Turkish undergraduate nursing students and its reflection on caring behaviour. Kontak. 2017;19(2):e116-e121. doi:10.1016/j.kontakt.2017.03.003.

13. Hung CA, Wu PL, Liu NY, Hsu WY, Lee BO, Pai HC. The effect of gender-friendliness barriers on perceived image in nursing and caring behaviour among male nursing students. Journal of Clinical Nursing. 2019;28(9-10):1465-1472. doi:10.1111 / jocn.14693.

14. Gökşin İ, Erzincanlı S. Hemşirelik öğrencilerinin toplumsal cinsiyet rollerine yönelik tutumları ile bakım davranışları arasındaki ilişki. Türkiye Klinikleri Hemşirelik Bilimleri Dergisi. 2020;12(1):49-55. doi:10.5336/nurses.2019-66259.

15. Kılıç M. Students' perceptions of nursing care: the case of a city of south Turkey. International Journal of Caring Sciences. 2018;11(1):402:408.

16. Loke JCF, Lee KW, Lee BK, Noor AM. Caring behaviours of student nurses: Effects of preregistration nursing education. Nurse Education in Practice. 2015;15:421-429. doi:10.1016/j.nepr.2015.05.005.

17. Okumuş ÇD, Uğur E. Hemşirelerin duygusal zekâ düzeylerinin bakım davranışlarına etkisi. ACU Sağllk Bilimleri Dergisi. 2017;2:104-109.

18. Shmilovitz R, Itzhaki M, Koton S. Associations between gender, sex types and caring behaviours among nurses in mental health. Journal Of Psychiatric And Mental Health Nursing. 2020;00:1-8. doi: 10.1111/jpm.12694.

19. Türk G, Adana F, Erol F, Çevik AR, Taşkıran N. Hemşirelik öğrencilerinin meslek seçme nedenleri ile bakım davranışları algısı. Gümüşhane Üniversitesi Sağhk Bilimleri Dergisi. 2018;7(3):1-10.

20. Dığın F, Kızılcık Özkan, Z. Hemşirelik Öğrencilerinin Bakım Davranışları Algılarının Belirlenmesi. Gevher Nesibe Journal Of Medical \& Health Scrences. 2021;6(10):16-21. doi: http://dx.doi.org/10.46648/gnj.155. 
21. Gül Ş, Arslan S. Bir hemşirelik bölümünde öğrenim gören öğrencilerin hemşirelik bakım davranışları algısının belirlenmesi. Acıbadem Üniversitesi Sağllk Bilimleri Dergisi. 2021;12(2):432-438. https://doi.org/10.31067/acusaglik.852191.

22. Wolf ZR, Giardino ER, Osborne PA, Ambrose MS. Dimensions of nurse caring. J. of Nursing Scholarship. 1994;26(2):107-111. doi: 10.1111/j.1547-5069.1994.tbo0927.x.

23. Labrague LJ, McEnroe-Petitte DM, Papathanasiou IV, Edet OB, Arulappan J, Tsaras K. Nursing students' perceptions of their own caring behaviors: A multicountry study. International Journal of Nursing Knowledge. 2015;1-8. doi: 10.1111 / 2047-3095.12108.

24. Uzelli YD, Akın E, Khorshid L. Bir palyatif bakım kliniğinde hemşirelik bakım kalitesinin değerlendirilmesi. Journal of Human Sciences. 2017;14(3):2968-2980.

25. Ahmad M, Safadi R. Entry criteria and increasing students' success. Jordan Medical Journal. 2009;43(3):189-195.

26. Safadi RR, Saleh MYN, Nassar OS, Amre HM, Froelicher ES. Nursing students' perceptions of nursing: A descriptive study of four cohorts. Int Nurs Rev. 2011;58:420-427. doi: 10.1111 / j.1466-7657.2011.00897.x. 